\title{
Earth and Environmental Science
}

\section{Transactions of the Royal Society of Edinburgh}

\section{volume 112 Issue 1 \\ March 2021}

Late Ordovician-Early Silurain

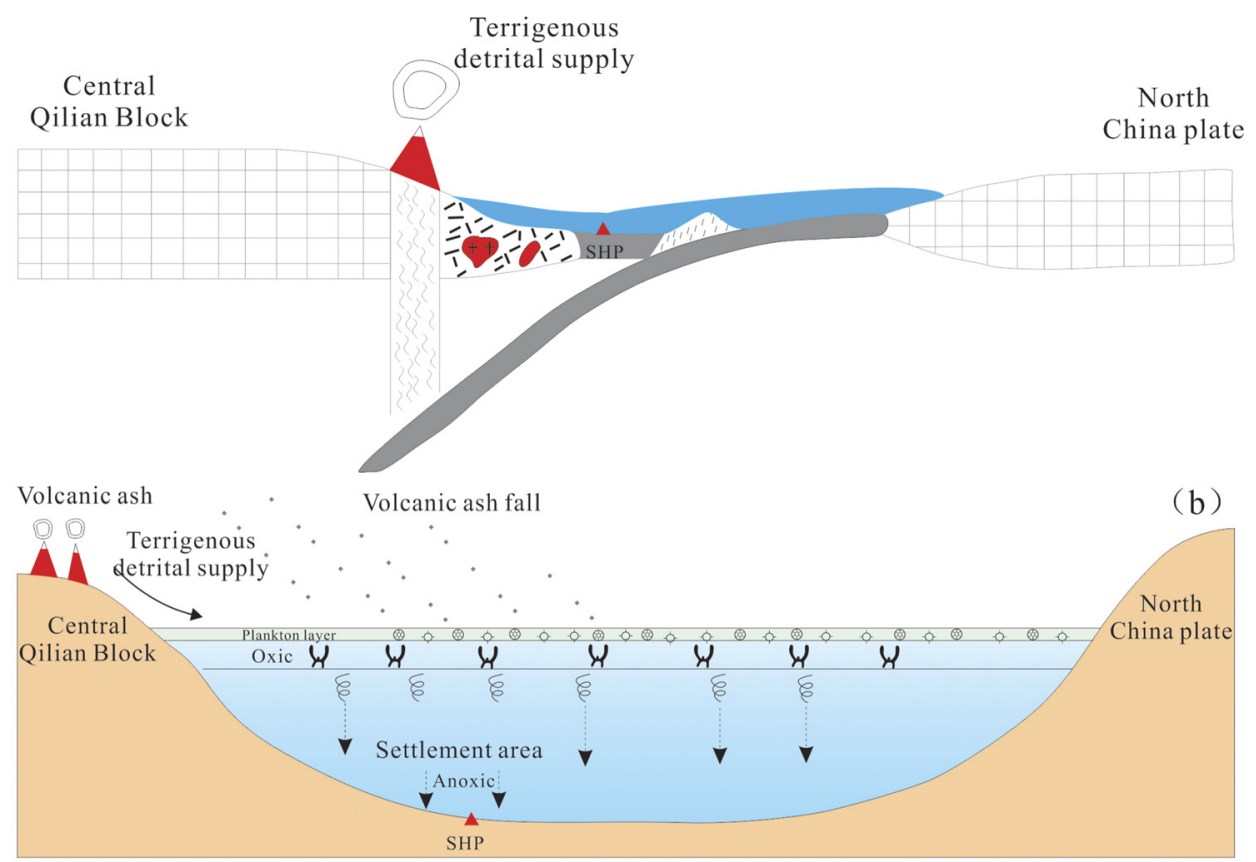

(a)

(b)

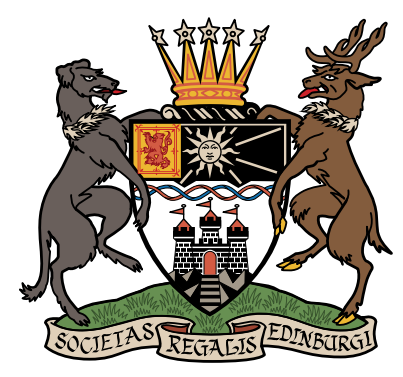


The Royal Society of Edinburgh is committed to the widespread dissemination of scientific knowledge and has published the Transactions of the Royal Society of Edinburgh since 1785, when James Hutton's 'Theory of the Earth' was published in Volume 1. The journal evolved to the Transactions of the Royal Society of Edinburgh: Earth Sciences in 1980 and is now (as from 2007) the Earth and Environmental Science Transactions of the Royal Society of Edinburgh. Through this journal, the Society continues to encourage and support the international Earth and Environmental Science communities by:

- $\quad$ publishing a journal of international standing and authorship;

- $\quad$ publishing substantial papers on all scientific aspects of the Earth and its surface environments;

- $\quad$ publishing without page or colour charges;

- $\quad$ reproducing photographs and artwork to the highest standard, where appropriate at a size larger than is customary; and

- $\quad$ aiming to have papers reviewed within three months by at least two referees of international standing; and usually publishing within six months of acceptance.

The Editorial Board welcomes original manuscripts in the Earth and Environmental Sciences. It also welcomes proposals for Special Issues in these areas.

Earth and Environmental Science Transactions of the Royal Society of Edinburgh publishes peer-reviewed, original scientific research papers, reviews and short communications on fields across the broad spectrum of the Earth and its surface environments. Articles do not need to have a specifically Scottish focus, nor are authors required to be Fellows of the Society. Articles should have relevance to a worldwide audience, even if the study is focused on a single geographic site. Papers should make topical, substantial and scholarly contributions, and the Editors are keen to encourage interdisciplinary papers. Discussions of articles previously published in the Transactions and reviews of topics of current interest are also invited. There are no page charges and all new submissions are sent to at least two reviewers. Any questions regarding the submission process should be sent to the Editorial Office at eestrse@cambridge.org.

COPYRIGHT: It is the policy of the Royal Society of Edinburgh not to charge any royalty for the production of a single copy of any one article made for private study or research. Specific permission will not be required for photocopying multiple copies of copyright material, to be used for bona fide educational purposes, provided this is done by a member of the staff of the university, school or other comparable institution, for distribution without profit to student members of that institution, and provided the copies are made from the original journal. Requests for the copying or reprinting of any article for any other purpose should be sent to Cambridge University Press.

Earth and Environmental Science Transactions of the Royal Society of Edinburgh is published as one volume of four parts per year, usually in a combination of single and double issues.

This journal is included in Cambridge Core and can be found at cambridge.org/tre. The EESTRSE Notes for Authors can be found online. Please email the Editorial Office at eestrse@cambridge.org if you have any questions.

EESTRSE is indexed/abstracted in the following: Current Contents/Physical, Chemical \& Earth Sciences; Biosciences Information Service; Geoabstracts; GEOBASE; Mineralogical Abstracts; Science Citation Index; SciSearch; VINITI (All-Russian Institute of Scientific and Technical Information); Zoological Record.

Subscription orders should be placed with Cambridge University Press, Journals Fulfilment Department, UPH, Shaftesbury Road, Cambridge CB2 8BS, UK. Telephone: 44 (0)1223 326070; Fax: 44 (0)1223 325150; email: journals@ cambridge.org

Printed in the United Kingdom by Bell \& Bain Ltd Glasgow.

This journal issue has been printed on $\mathrm{FSC}^{\mathrm{TM}}$-certified paper and cover board. FSC is an independent, non-governmental, not-for-profit organization established to promote the responsible management of the world's forests. Please see www.fsc.org for more information.

ISSN 1755-6910 @ 2021 The Royal Society of Edinburgh

The Royal Society of Edinburgh, Scotland's National Academy, is Scottish Charity No. SC000470

Cover image: top left - Skeletal reconstructions and size comparisons of erpetosuchids (Archosauria); top right - Molossid bat (Chiroptera) tooth, Cuvierimops penalveri sp. nov.; bottom left - Upper Lishi Loess, Guanzhong Basin; bottom right - Three-dimensional scatter plot of sediment samples from Luguhu Lake. 